\title{
lonizing radiation induced degradation of diuron in dilute aqueous solution
}

\author{
Krisztina Kovács ${ }^{1}$, Shijun He${ }^{2}$, Viktoria Mile ${ }^{1}$ Tamás Csay ${ }^{1}$, Erzsébet Takács ${ }^{1,3^{*}}$ and László Wojnárovits $^{1}$
}

\begin{abstract}
Background: Cutting edge technologies based on Advanced Oxidation Processes (AOP) are under development for the elimination of highly persistent organic molecules (like pesticides) from water matrices. Among them, ionizing radiation treatment represents a promising technology that requires no additives and can be easily adapted to an industrial scale. In these processes several reactive species are produced, mainly powerful oxidizing radicals inducing the degradation. This paper investigates the reactions taking place in dilute aqueous solutions of a hazardous pollutant (diuron) during irradiation.

Results: Irradiation of aqueous diuron solutions resulted in effective degradation of the solute mainly due to the reactions of hydroxyl radicals formed in water radiolysis. Hydroxyl radical reacts with diuron with a second order rate constant of $(5.8 \pm 0.3) \times 10^{9} \mathrm{~mol}^{-1} \mathrm{dm}^{3} \mathrm{~s}^{-1}$. The main reaction is addition to the ring forming hydroxycyclohexadienyl radical. $30-50 \%$ of hydroxyl radical reactions induce dechlorination. Reactions with the methyl groups or with the a-amino group have low contribution to the transformation. The presence of dissolved oxygen enhances the rate of degradation; one hydroxyl radical on average induces five-electron oxidations. The high oxidation rate is attributed to the reaction of some of the primarily formed organic radicals with dissolved $\mathrm{O}_{2}$ and the subsequent reactions of the peroxy radicals.
\end{abstract}

Conclusion: The presence of dissolved oxygen is highly important to achieve efficient ionizing radiation induced degradation of diuron in dilute aqueous solution.

Keywords: Diuron, Hydroxyl radical, Degradation, Advanced oxidation processes, Irradiation technology

\section{Background}

Diuron, a phenylurea herbicide, has been used worldwide in agriculture to control broadleaf and grassy weeds in cereals and other crops for more than 50 years. Diuron is highly persistent in the aquatic environment due to its photochemical stability. As a consequence, it has been detected in wastewater effluents and in surface waters at low concentrations up to the $\mu \mathrm{g} \mathrm{dm}^{-3}$ level. As a potentially carcinogenic substance, its occurrence in such reservoirs poses serious threat to human health and it is also toxic to microorganisms. The European Water Framework Directive classifies diuron as one of the priority substances, being a hazardous pollutant [1].

\footnotetext{
* Correspondence: erzsebet.takacs@energia.mta.hu

${ }^{1}$ Institute for Energy Security and Environmental Safety, Centre for Energy

Research, Hungarian Academy of Sciences, Budapest, Hungary

${ }^{3}$ Faculty of Light Industry and Environmental Engineering, Obuda-University,

Budapest, Hungary

Full list of author information is available at the end of the article
}

Diuron is also included in the drinking water contaminant candidate list of the U.S. Environmental Protection Agency [2], to enforce further research and data collection.

Advanced Oxidation Processes (AOP) are suggested for the elimination of persistent organic compounds from water matrices. The radical induced degradation of diuron has been investigated formerly using several AOP [3-7]. In these experiments, with the exception of direct photodegradation, hydroxyl radical was the main oxidizing agent. Mazellier and Sulzberger [8] observed only one product in heterogenous photo-Fenton system (3-(3,4-dichlorophenyl)-1-formyl-1-methylurea), indicating ${ }^{\circ} \mathrm{OH}$ attack on the methyl group. In other experiments using ozonation or photocatalytic oxidation, the ${ }^{\cdot} \mathrm{OH}$ attack took place on the aromatic ring leading to hydroxylated or dechlorinated products.

The ionizing radiation treatment is one of the AOP. In establishing reaction mechanisms radiation chemistry 
provides the advantage of investigating the radical intermediates by electron pulse radiolysis (their yields can be easily calculated) and additionally achieving the final products by utilizing ${ }^{60} \mathrm{Co} \gamma$-irradiation. Radiation technology can be applied on an industrial scale [9]. The aim of the present study is to investigate both the intermediates and the final products of diuron degradation induced by water radiolysis techniques. In order to promote the practical application we also determined sum parameters important in wastewater analysis: chemical oxygen demand (COD), total organic carbon (TOC) and total nitrogen content (TN). To the best of our knowledge, there is only one publication reporting the radiation induced degradation of diuron [10]. In a previous paper we have already reported on the degradation of fenuron [11].

\section{Materials and methods}

\section{Chemicals and equipment}

Diuron and other chemicals were purchased from Spectrum-3D or Carlo Erba and used without further purification. HPLC grade eluents for liquid chromatographic analysis were obtained from Fischer Chemicals. All solutions were prepared at their natural $\mathrm{pH}$. The absorption spectra of the irradiated samples were recorded on a JASCO $550 \mathrm{UV}$-Vis spectrophotometer in a $1 \mathrm{~cm}$ cell. Appropriate dilutions were applied in order to stay within the linear range of the Lambert-Beer relation. An Agilent Technologies 6410 Triple Quad HPLC-MS/ MS system was used for final product identification. Liquid chromatographic separations were carried out on a Phenomenex Kinetex Phenyl-Hexyl column $(100 \mathrm{~mm} \times$ $2.1 \mathrm{~mm} \times 2.6 \mu \mathrm{m}$ ) using isocratic elution mode at a flow rate of $0.25 \mathrm{~cm}^{3} \mathrm{~min}^{-1}$. The mobile phase composed of $45 \%$ methanol and $55 \%$ water. The concentration of adsorbable organic halides (AOX) and free chloride ions were monitored by $\mathrm{AOX}$ equipment and perfectION ${ }^{\mathrm{TM}}$ Combination Chloride Electrode, respectively. COD measurements were performed with a Behrotest TRS 200 COD system. TOC and TN were measured using Shimadzu TOC-VCSN equipment.

\section{Pulse radiolysis and steady-state gamma irradiation}

Pulse radiolysis was performed using $800 \mathrm{~ns}$ pulses of a linear accelerator, and an optical detection system with a cell having $1 \mathrm{~cm}$ light path length [12]. Pulse dosimetry was carried out in air-saturated, $1 \times 10^{-2} \mathrm{~mol} \mathrm{dm}^{-3}$ KSCN solutions by monitoring the absorbance of $(\mathrm{SCN})_{2}{ }^{-\cdot}$ at $\lambda_{\max } 480 \mathrm{~nm}$. The absorbed doses per pulse were $20 \mathrm{~Gy}$. A ${ }^{60} \mathrm{Co}$ gamma facility with $1.8 \mathrm{PBq}$ activity was used for steady-state gamma irradiation. The dose rate was measured to be $\sim 10 \mathrm{kGy} \mathrm{h}^{-1}$ using ethanolmonochlorobenzene $(\mathrm{ECB})$ dosimetry.
In the radiolysis of water, hydrated electron $\left(\mathrm{e}_{\mathrm{aq}}^{-}\right)$, hydrogen atom $\left(\mathrm{H}^{*}\right)$ and hydroxyl radical $\left({ }^{\circ} \mathrm{OH}\right)$ form as reactive intermediates as shown in Eq. (1) [13,14].

$$
\begin{aligned}
& \mathrm{H}_{2} \mathrm{O}_{\mathrm{aq}^{\rightsquigarrow »}}(0.28)+\mathrm{H}^{\cdot}(0.07)+\cdot \mathrm{OH}(0.28) \\
& \mathrm{e}_{\mathrm{aq}}{ }^{-}+\mathrm{N}_{2} \mathrm{O}+\mathrm{H}_{2} \mathrm{O} \rightarrow \mathrm{OH}^{-}+\cdot \mathrm{OH} \\
& +\mathrm{N}_{2}\left(k=9.1 \times 10^{9} \mathrm{~mol}^{-1} \mathrm{dm}^{3} \mathrm{~s}^{-1}\right)
\end{aligned}
$$

$$
\begin{gathered}
\cdot \mathrm{OH}+\left(\mathrm{CH}_{3}\right)_{3} \mathrm{COH} \rightarrow{ }^{\cdot} \mathrm{CH}_{2}\left(\mathrm{CH}_{3}\right)_{2} \mathrm{COH} \\
+\mathrm{H}_{2} \mathrm{O}\left(k=6 \times 10^{8} \mathrm{~mol}^{-1} \mathrm{dm}^{3} \mathrm{~s}^{-1}\right)
\end{gathered}
$$

$$
\mathrm{e}_{\mathrm{aq}}{ }^{-}+\mathrm{O}_{2} \rightarrow \mathrm{O}_{2}{ }^{-\bullet}\left(k=1.9 \times 10^{10} \mathrm{~mol}^{-1} \mathrm{dm}^{3} \mathrm{~s}^{-1}\right)
$$

$$
\mathrm{H}^{\cdot}+\mathrm{O}_{2} \rightarrow \mathrm{HO}_{2} \cdot\left(k=2.1 \times 10^{10} \mathrm{~mol}^{-1} \mathrm{dm}^{3} \mathrm{~s}^{-1}\right)
$$

$$
\mathrm{HCO}_{2}^{-}+{ }^{-} \mathrm{OH} \rightarrow \mathrm{CO}_{2}^{-\bullet}+\mathrm{H}_{2} \mathrm{O}\left(k=3 \times 10^{9} \mathrm{~mol}^{-1} \mathrm{dm}^{3} \mathrm{~s}^{-1}\right)
$$

$$
\mathrm{CO}_{2} \cdot{ }^{\bullet}+\mathrm{O}_{2} \rightarrow \mathrm{O}_{2} \cdot \bullet+\mathrm{CO}_{2}\left(k=4.2 \times 10^{9} \mathrm{~mol}^{-1} \mathrm{dm}^{3} \mathrm{~s}^{-1}\right)
$$

In Eq. (1) the numbers in parentheses are the radiation chemical yields ( $G$-values) in $\mu \mathrm{mol} \mathrm{J}^{-1}$. Standard radiation chemical techniques were applied in the experiments in order to observe the individual reactions of the intermediates. The ${ }^{\circ} \mathrm{OH}$ reactions were followed in $\mathrm{N}_{2} \mathrm{O}$ saturated solutions to convert $\mathrm{e}_{\mathrm{aq}}^{-}$to ${ }^{\circ} \mathrm{OH}$ in Reaction (2). Reactions between $\mathrm{e}_{\mathrm{aq}}^{-}$and diuron were investigated in $\mathrm{N}_{2}$-saturated solutions containing 5 vol. \% tert-butanol to convert ${ }^{\circ} \mathrm{OH}$ to the less reactive ${ }^{\circ} \mathrm{CH}_{2}\left(\mathrm{CH}_{3}\right)_{2} \mathrm{COH}$ in Reaction (3). When the solution was purged with $\mathrm{N}_{2}$ in the absence of tert-butanol, all the three primary species reacted with diuron. In the presence of dissolved $\mathrm{O}_{2}$ (air or $\mathrm{O}_{2}$ saturated solutions), $\mathrm{e}_{\mathrm{aq}}^{-}$and $\mathrm{H}^{*}$ are converted to superoxide radical anion/perhydroxyl radical pair in Reactions ((4) and (5)). Hence, in these solutions ' $\mathrm{OH}$ as well as the $\mathrm{O}_{2}^{-*} / \mathrm{HO}_{2}^{\cdot}$ pair induce the transformations $\left(\mathrm{p} K_{\mathrm{a}}\left(\mathrm{O}_{2}^{-*} / \mathrm{HO}_{2}^{*}\right)=4.8\right)$. Experiments were also made in $\mathrm{O}_{2}$ saturated solutions containing $\mathrm{Na}$ formate $\left(0.05 \mathrm{~mol} \mathrm{dm}^{-3}\right)$. In such solutions (in addition to $\mathrm{e}_{\mathrm{aq}}^{-}$ and $\left.\mathrm{H}^{*}\right){ }^{\circ} \mathrm{OH}$ is transformed to $\mathrm{O}_{2}^{-*} / \mathrm{HO}_{2}^{*}$ in Reactions (6) and (7).

In most of the experiments $\sim 1 \times 10^{-4} \mathrm{~mol} \mathrm{dm}^{-3}$ diuron solutions were investigated, they were saturated with appropriate gases $\left(\mathrm{N}_{2} \mathrm{O}, \mathrm{N}_{2}, \mathrm{O}_{2}\right.$ or air) before irradiation. 


\section{Results}

\section{Pulse radiolysis}

In the transient absorption spectra taken on samples investigating the ${ }^{\circ} \mathrm{OH}$ reaction $\left(\mathrm{N}_{2} \mathrm{O}\right.$ saturated), three absorption bands were observed: two shorter wavelength bands peaking at $\sim 330 \mathrm{~nm}$ and $\sim 360 \mathrm{~nm}$ and a longer wavelength band with maximum around $460 \mathrm{~nm}$ (Figure 1). The build-up of these three bands was similar. In separate experiments we added $\mathrm{K}_{3} \mathrm{Fe}(\mathrm{CN})_{6}$ to the solution with equal concentration as diuron. In these solutions the $\sim 360 \mathrm{~nm}$ band had smaller intensity and it decayed quickly. The decay of the $\sim 460 \mathrm{~nm}$ band took place on the ms time scale.

In general, ${ }^{\circ} \mathrm{OH}$ is a highly reactive electrophilic radical, in its reaction with diuron, however, direct oxidation (electron transfer) hardly occurs [5]: the basic reactions are addition to the ring and $\mathrm{H}$-abstraction from one of the $\mathrm{CH}_{3}$ groups or from the $\mathrm{N}-\mathrm{H}$ group. The absorption band at $\sim 360 \mathrm{~nm}$ is typical for the hydroxycyclohexadienyl radicals: e.g. for the chloroanilines the maxima of the bands are around $360 \mathrm{~nm}$ [15]. For fenuron the maximum is at $350 \mathrm{~nm}$ [11]. Therefore, we assign the $\sim 360 \mathrm{~nm}$ band to hydroxycyclohexadienyl radical isomers. Ring-hydroxylated products identified by HPLC-MS/MS technique provide further confirmation. In addition, this identification is in agreement with the fast decrease of this absorption band in the presence of $\mathrm{K}_{3} \mathrm{Fe}(\mathrm{CN})_{6}$. This additive is known to oxidize cyclohexadienyl type radicals to phenols in fast reactions.

The longer wavelength band at $\lambda_{\max } \sim 460 \mathrm{~nm}$ (and partly the band at $330 \mathrm{~nm}$ ) may belong to (oxygen centred) phenoxyl radicals or to (nitrogen centred) aminyl radical. As it will be discussed later, phenoxyl radical may form after release of $\mathrm{HCl}$ from the ${ }^{\circ} \mathrm{OH}$ adducts. In the case of hydroxyanilines the $\lambda_{\max }$ of phenoxyl radicals are around $440 \mathrm{~nm}$ [15]. Aminyl radical can form in $\mathrm{H}$-abstraction from $\mathrm{N}-\mathrm{H}$ group. These radicals are observed in the reaction of $\mathrm{SO}_{4}^{--}$with phenylureas and also in photoionization experiments. In the case of diuron $\lambda_{\max } \approx 450 \mathrm{~nm}$ and $\varepsilon_{\max } \approx 2000 \mathrm{~mol}^{-1} \mathrm{dm}^{3} \mathrm{~cm}^{-1}$ are suggested [3]. Based on the absorption spectra we cannot make a clear assignment for the longer wavelength band. Based on end product experiments (phenol formation) this absorbance can be attributed to phenoxyl radical. Considering the band intensity we can also safely say that $\mathrm{H}$-abstraction from N-H is less important than the other reactions of ${ }^{\circ} \mathrm{OH}$.

The radical that forms in $\mathrm{H}$-abstraction from a $\mathrm{CH}_{3}$ group is expected to exhibit UV absorbance below $300 \mathrm{~nm}$. However, under our circumstances it is invisible since below $300 \mathrm{~nm}$ the absorbance of diuron disturbs observing the transient absorbance.

The rate constant of the diuron $+{ }^{\circ} \mathrm{OH}$ reaction was determined by varying the diuron concentration and measuring the build-up of radical absorbance. The slope of the pseudo-first-order rate constant versus diuron concentration plot suggests a second order rate constant of $(5.8 \pm 0.3) \times 10^{9} \mathrm{~mol}^{-1} \mathrm{dm}^{3} \mathrm{~s}^{-1}$ (Figure 1, Inset). This value is in agreement with the rate constants published previously: their average is calculated to be $6.0 \times$ $10^{9} \mathrm{~mol}^{-1} \mathrm{dm}^{3} \mathrm{~s}^{-1}[16]$.

In pulse radiolysis experiments with $\mathrm{N}_{2}$-saturated solution containing tert-butanol ( $\mathrm{e}_{\mathrm{aq}}^{-}$reaction) low transient

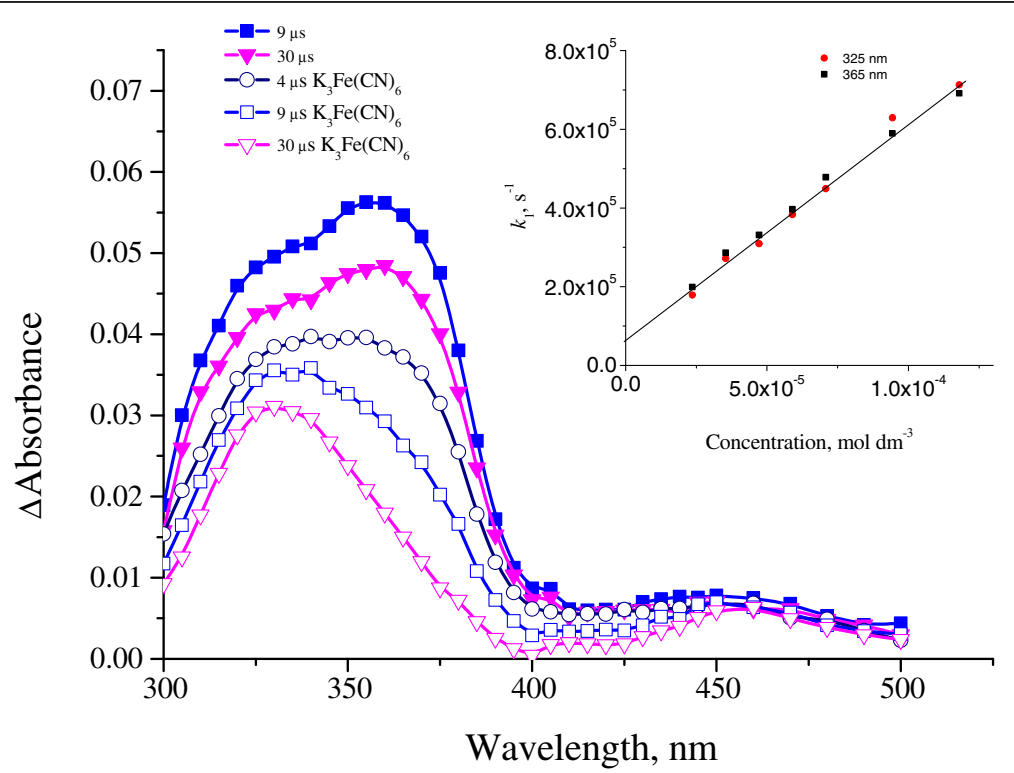

Figure 1 Transient absorption spectra in $\mathrm{N}_{2} \mathrm{O}$ saturated, $1 \times 10^{-4} \mathrm{~mol} \mathrm{dm}{ }^{-3}$ diuron solutions. Closed symbols in the absence, open symbols in the presence of $1 \times 10^{-4} \mathrm{~mol} \mathrm{dm}{ }^{-3} \mathrm{~K}_{3} \mathrm{Fe}(\mathrm{CN})_{6}$, dose/pulse $20 \mathrm{~Gy}$. Inset: concentration dependence of pseudo-first-order rate constant of absorbance build-up at 325 and $365 \mathrm{~nm}$. 
absorbance was obtained in the $300-400 \mathrm{~nm}$ range (not shown) with maximum at $\sim 350 \mathrm{~nm}$. Based on the hydrated electron absorbance decay at $600 \mathrm{~nm}$, we calculated a rate constant of $1.0 \times 10^{10} \mathrm{~mol}^{-1} \mathrm{dm}^{3} \mathrm{~s}^{-1}$ for the $\mathrm{e}_{\mathrm{aq}}^{-}+$diuron reaction. Canle Lopez et al. [3] measured $(9.4 \pm 0.6) \times 10^{9} \mathrm{~mol}^{-1} \mathrm{dm}^{3} \mathrm{~s}^{-1}$ previously.

\section{Steady-state gamma radiolysis}

The degradation of diuron in gamma radiolysis was followed by UV-Vis spectroscopy and by COD, TOC and TN measurements. Product analysis was also performed using HPLC-MS/MS technique. The band between 230 and $270 \mathrm{~nm}$ in the UV spectrum is assigned to the characteristic $\pi \rightarrow \pi^{*}$ transition of the aromatic ring, $\lambda_{\max }$ is at $248 \mathrm{~nm}$ with $\varepsilon_{\max }$ of $17000 \mathrm{~mol}^{-1} \mathrm{dm}^{3} \mathrm{~cm}^{-1}$. The absorbance decreased faster when ${ }^{\circ} \mathrm{OH}$ was the reacting species (Figure 2a) than in $\mathrm{e}_{\mathrm{aq}}^{-}$reaction (Figure 2b).
Moreover, in ${ }^{\circ} \mathrm{OH}$ reaction at $\sim 300 \mathrm{~nm}$ increase in absorbance was observed, this build-up was absent in $\mathrm{e}_{\mathrm{aq}}^{-}$reaction. In both ${ }^{\circ} \mathrm{OH}$ and $\mathrm{e}_{\mathrm{aq}}^{-}$reactions the absorption band slightly shifted to shorter wavelength. This shift may reflect dehalogenation. $\lambda_{\max }$ for the monohalogenated monuron and the non-halogenated fenuron are at 245 and $238 \mathrm{~nm}\left(\varepsilon_{\max }\right.$ 15377 and $13104 \mathrm{~mol}^{-1} \mathrm{dm}^{3} \mathrm{~cm}^{-1}$, respectively).

As the integrated chromatographic peak areas (diode array detection) show in Figure 3, at a dose of $1 \mathrm{kGy}$ the majority of diuron degraded in $\mathrm{N}_{2} \mathrm{O}\left({ }^{\circ} \mathrm{OH}\right), \mathrm{N}_{2}\left({ }^{\circ} \mathrm{OH}+\right.$ $\left.\mathrm{e}_{\mathrm{aq}}^{-}\right)$and air saturated $\left({ }^{\circ} \mathrm{OH}+\mathrm{O}_{2}^{-\cdot} / \mathrm{HO}_{2}^{*}\right)$ solutions, only a few percent of the intact molecules remained. In $\mathrm{N}_{2}$ saturated tert-butanol containing solutions $\left(\mathrm{e}_{\mathrm{aq}}^{-}\right)$, however, the degradation was much slower; the initial yield was $\sim 0.15 \mu \mathrm{mol} \mathrm{J^{-1 }}$. In air and $\mathrm{N}_{2} \mathrm{O}$ saturated solutions the values were estimated to be $\sim 0.2 \mu \mathrm{mol} \mathrm{J}^{-1}$ and $\sim 0.3 \mu \mathrm{mol} \mathrm{J}^{-1}$, respectively.
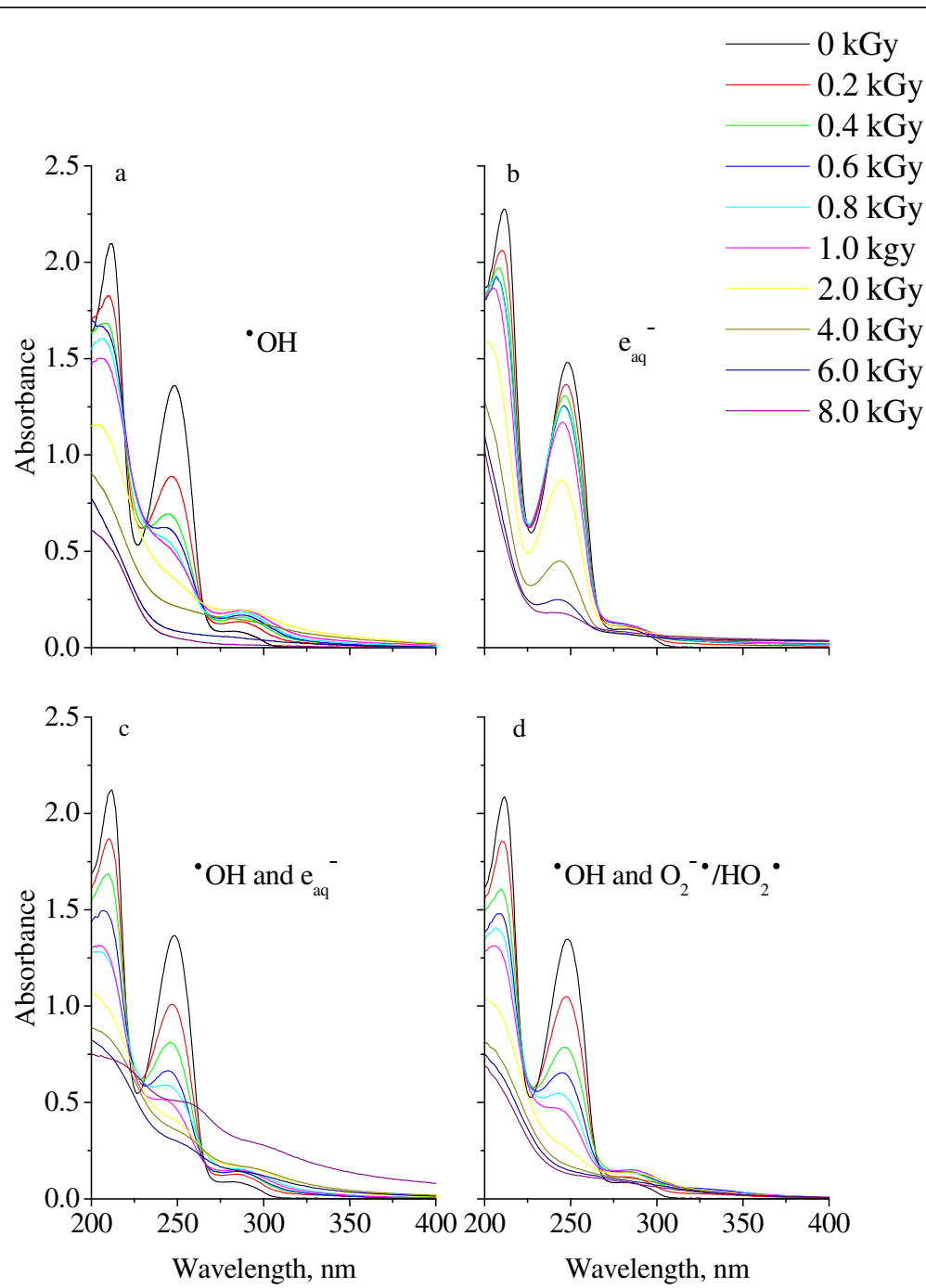

Figure 2 Absorption spectra of $1.6 \times 10^{-4} \mathrm{~mol} \mathrm{dm^{-3 }}$ diuron solution. Irradiation with $0-8 \mathrm{kGy}$ doses, the spectra were obtained in ${ }^{\circ} \mathrm{OH}$ (a), $\mathrm{e}_{\mathrm{aq}}^{-}$ (b), $\mathrm{OH}+\mathrm{e}_{\mathrm{aq}}^{-}$(c) and in ${ }^{\circ} \mathrm{OH}+\mathrm{O}_{2}^{-\cdot} / \mathrm{HO}_{2}^{*}$ (d) reactions. 


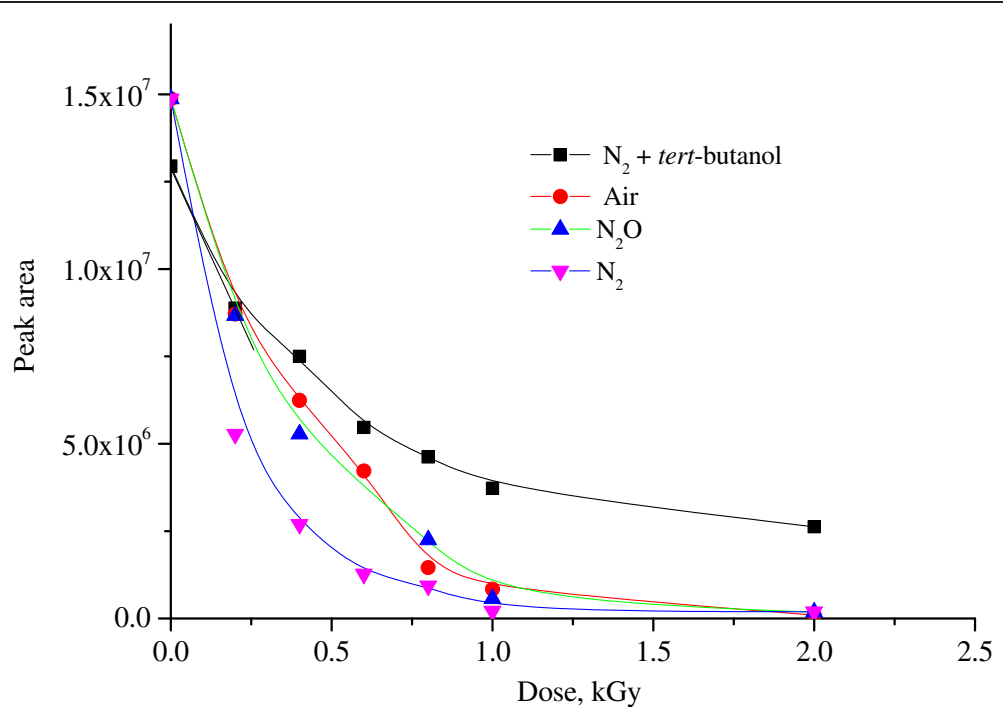

Figure 3 Integrated diuron peaks obtained after HPLC-MS/MS analysis (optical detection). $1 \times 10^{-4} \mathrm{~mol} \mathrm{dm}^{-3}$ solution was irradiated under different conditions indicated in the Figure.

\section{Identification of by-products by HPLC-MS/MS}

A large number of products were observed on the chromatograms, their composition changed gradually as a function of dose. The distribution was different in air- and $\mathrm{N}_{2} \mathrm{O}$ saturated solutions (Figure 4). At $0.5 \mathrm{kGy}$ dose in both solutions about $50-70 \%$ of the starting molecules transformed to products: 14 different compounds were separated. The large variation is partly due to the possible presence of isomers and also to the thermal instability and decomposition of some of the products. Diuron eluted at $14.34 \mathrm{~min}$ and in negative ionization mode had a parent ion with $\mathrm{m} / \mathrm{z}$ 231. Two compounds with $\mathrm{m} / \mathrm{z} 247$ eluted earlier than diuron at 6.89 and $14.13 \mathrm{~min}$, respectively. We identified these molecules as ring hydroxylated derivatives of diuron. The ion at $\mathrm{m} / \mathrm{z} 247$ had an intensive fragment with $\mathrm{m} / \mathrm{z}$ 202. This $\mathrm{m} / \mathrm{z} 202$ ion appeared also for the ring hydroxylated products with modified $-\mathrm{N}\left(\mathrm{CH}_{3}\right)_{2}$ unit: with one $\mathrm{CH}_{3}$ group missing (parent ion at $\mathrm{m} / \mathrm{z} 233,8.37$ and $10.12 \mathrm{~min}$ ), and hydroxylated molecules with one $\mathrm{CH}_{3}$ oxidized to $\mathrm{CHO}(\mathrm{m} / \mathrm{z} 261,16.31$ and $25.89 \mathrm{~min})$. In the case of two products at 16.93 and $19.50 \mathrm{~min}$ no ion with higher $\mathrm{m} / \mathrm{z}$ than 202 appeared, indicating a complete ionic degradation of the parent ion in the mass spectrometer. In the case of molecules with one $\mathrm{Cl}$ only (parent ion $\mathrm{m} / \mathrm{z} 213,2.19$ and $2.32 \mathrm{~min}), \mathrm{m} / \mathrm{z} 202$ was not present and another fragment at $\mathrm{m} / \mathrm{z} 168$ indicated a chlorine loss $(\mathrm{m} / \mathrm{z} 202-\mathrm{Cl})$. In the case of ring dihydroxylated molecule (parent ion at $\mathrm{m} / \mathrm{z}$ 263, $7.01 \mathrm{~min}$ ) the MS/MS spectra revealed a fragment at $\mathrm{m} / \mathrm{z} 218(\mathrm{~m} / \mathrm{z} 202+\mathrm{OH})$, which contains one more hydroxyl group compared to $\mathrm{m} / \mathrm{z}$ 202. The product with parent ion $\mathrm{m} / \mathrm{z} 249$ at $6.08 \mathrm{~min}$ was identified as ring dihydroxylated molecule with one methyl group missing, while the one with $\mathrm{m} / \mathrm{z} 277$ at $5.31 \mathrm{~min}$ as ring dihydroxylated product with one methyl group oxidized to - $\mathrm{CHO}$. Fragments with m/z 202, m/z $218(\mathrm{~m} / \mathrm{z} 202+\mathrm{OH})$ and m/z 168 $(\mathrm{m} / \mathrm{z} 202-\mathrm{Cl})$ are characteristic for ring hydroxylated

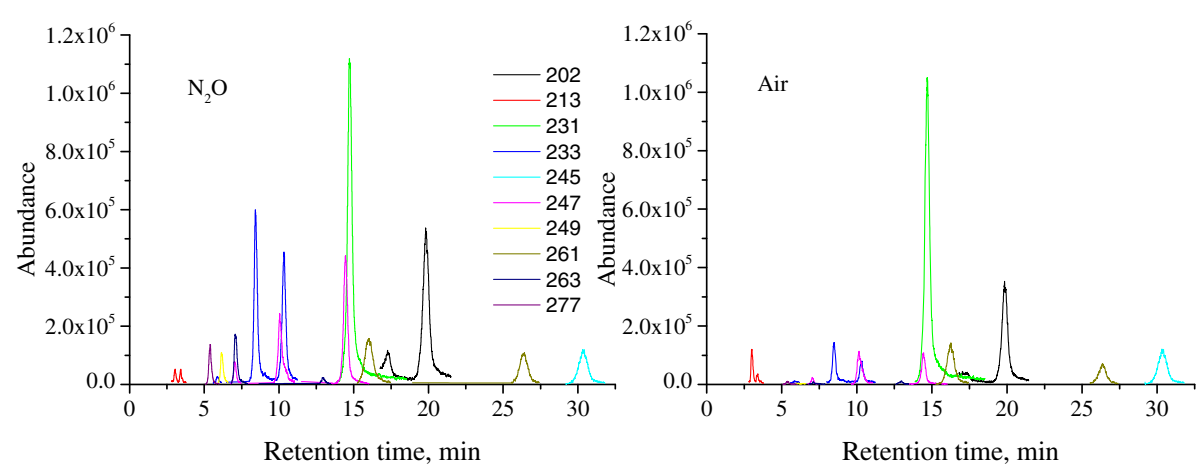

Figure 4 Chromatogram of $1 \times 10^{-4} \mathrm{~mol} \mathrm{dm}{ }^{-3}$ diuron solutions. Irradiation with $0.5 \mathrm{kGy}$ dose in $\mathrm{N}_{2} \mathrm{O}$ or air atmosphere. The peak of each selected ion is depicted with different colour and its $\mathrm{m} / \mathrm{z}$ value is indicated. 
molecules. They form isocyanate ion in the collision chamber, e.g. in the case of diuron: ${ }^{-} \mathrm{O}\left(\mathrm{Cl}_{2}\right) \mathrm{C}_{6} \mathrm{H}_{2} \mathrm{NHCON}\left(\mathrm{CH}_{3}\right)$ ${ }_{2} \rightarrow{ }^{-} \mathrm{O}\left(\mathrm{Cl}_{2}\right) \mathrm{C}_{6} \mathrm{H}_{2} \mathrm{~N}=\mathrm{C}=\mathrm{O}+\mathrm{HN}\left(\mathrm{CH}_{3}\right)_{2}$. Similar reaction (isocyanate ion formation) has also been observed in the thermal degradation of diuron [6] and during the mass spectrometric analysis of irradiated fenuron samples [11].

In the case of the molecule with elution time $29.64 \mathrm{~min}$ at $\mathrm{m} / \mathrm{z} 245$, the aromatic ring remained intact and one of the methyl groups was oxidized to - $\mathrm{CHO}$.

The products reveal that ${ }^{\circ} \mathrm{OH}$ attack takes place both on the ring and also on the methyl groups attached to the terminal $\mathrm{N}$ atom. Most of these products were observed also in previous studies where hydroxyl radicals were the initiating reactants $[4,7,10]$. According to Tahmasseb et al. [4] "The disubstitution of the phenyl ring by chlorine atoms reduces its susceptibility towards any electrophylic and/or radical attack which in counterpart makes the attack on the urea $\mathrm{N}$-terminus group more competitive." However, our results clearly show the predominance of ring hydroxylation reactions for diuron similarly to the reactions with fenuron [11].

Figure 4 suggests that the rate of hydroxylated product formation is higher in $\mathrm{N}_{2} \mathrm{O}$-saturated solution than under aerated condition. This difference may be due to the higher yield of hydroxyl radicals in the former solution than in the latter $\left(0.56\right.$ and $\left.0.28 \mu \mathrm{mol} \mathrm{J}^{-1}\right)$ and also to the reaction of the dissolved $\mathrm{O}_{2}$ with the organic radicals in aerated solution, opening up by that new reaction pathways at the expense of hydroxylated product formation (see later). Most of the products had maximum concentrations between 0.3 and $0.7 \mathrm{kGy}$ dose. At $1 \mathrm{kGy}$ dose strong decrease in product concentrations was observed.

\section{Chloride release and AOX}

Chloride release is an important indicator for the degradation of chlorinated molecules. It facilitates the understanding of the attack of reactive radicals on special sites of the molecule studied. Chloride release was observed under all conditions investigated (Figure 5), in the reactions of ${ }^{\circ} \mathrm{OH}, \mathrm{e}_{\mathrm{aq}}^{-},{ }^{\circ} \mathrm{OH}+\mathrm{e}_{\mathrm{aq}}^{-}$, and ${ }^{\circ} \mathrm{OH}+\mathrm{O}_{2}^{-\cdot} / \mathrm{HO}_{2}$. The percentages in the figure are calculated by taking into account both of the chlorine atoms in diuron. The initial (low-dose) yields for air saturated $\left({ }^{\circ} \mathrm{OH}+\mathrm{O}_{2}^{-*} / \mathrm{HO}_{2}\right), \quad \mathrm{N}_{2}$ saturated $\left(\mathrm{e}_{\mathrm{aq}}^{-}+{ }^{\cdot} \mathrm{OH}\right), \mathrm{N}_{2}$ saturated containing tert-butanol $\left(\mathrm{e}_{\mathrm{aq}}^{-}\right)$ and $\mathrm{N}_{2} \mathrm{O}$ saturated $\left({ }^{\circ} \mathrm{OH}\right)$ solutions are $\sim 0.15, \sim 0.1$, $\sim 0.08$ and $\sim 0.07 \mu \mathrm{mol}{ }^{-1}$. In $\mathrm{O}_{2}$-free solutions about $15-30 \%$ of ${ }^{\circ} \mathrm{OH}$ attack on diuron yields chloride ion, while this value is about $60 \%$ in solutions containing dissolved $\mathrm{O}_{2}$. The efficiency of $\mathrm{Cl}^{-}$release for $\mathrm{e}_{\mathrm{aq}}^{-}$ reaction is about $25 \%$.

We investigated the question whether the $\mathrm{O}_{2}^{-\bullet} / \mathrm{HO}_{2}$ pair directly induces chloride release. In order to examine the possibility of $\mathrm{O}_{2}^{-*} / \mathrm{HO}_{2}$ reaction with diuron, measurements were conducted in $\mathrm{O}_{2}$ saturated $\mathrm{Na}$ formate containing solutions. In such solutions all the three reactive intermediates of water radiolysis transform to the $\mathrm{O}_{2}^{-*} / \mathrm{HO}_{2}$ pair in Reactions (4) - (7). In solutions with $\mathrm{Na}$ formate the absorbance slightly decreased with increasing absorbed dose and the maximum slightly shifted to shorter wavelengths (not shown). However, the effect was small and was observable only at higher doses. As Figure 5 shows in $\mathrm{Na}$ formate solutions both the yield of chloride release and decrease of AOX were small at low doses.

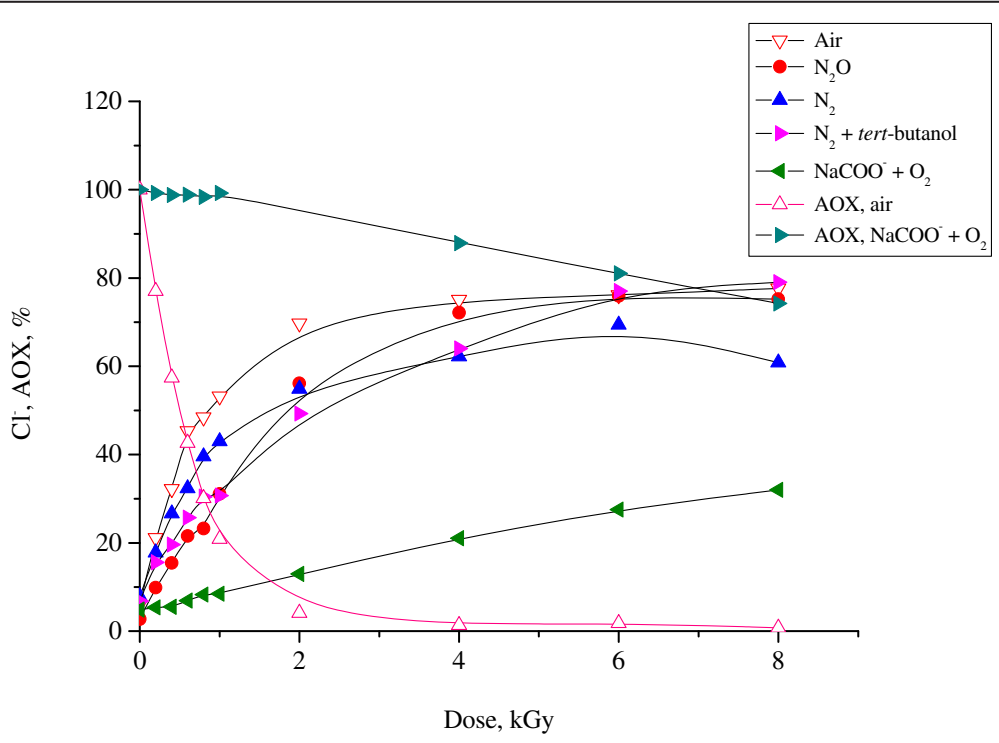

Figure 5 Chloride release $\left(\mathrm{Cl}^{-}\right)$and the adsorbable organic chloride (AOX). Chloride release was measured in different solutions (indicated in the Figure) AOX was measured in air and $\mathrm{O}_{2}$ saturated (Na-formate added) solution (diuron $1.1 \times 10^{-4} \mathrm{~mol} \mathrm{dm}^{-3}$ ). 


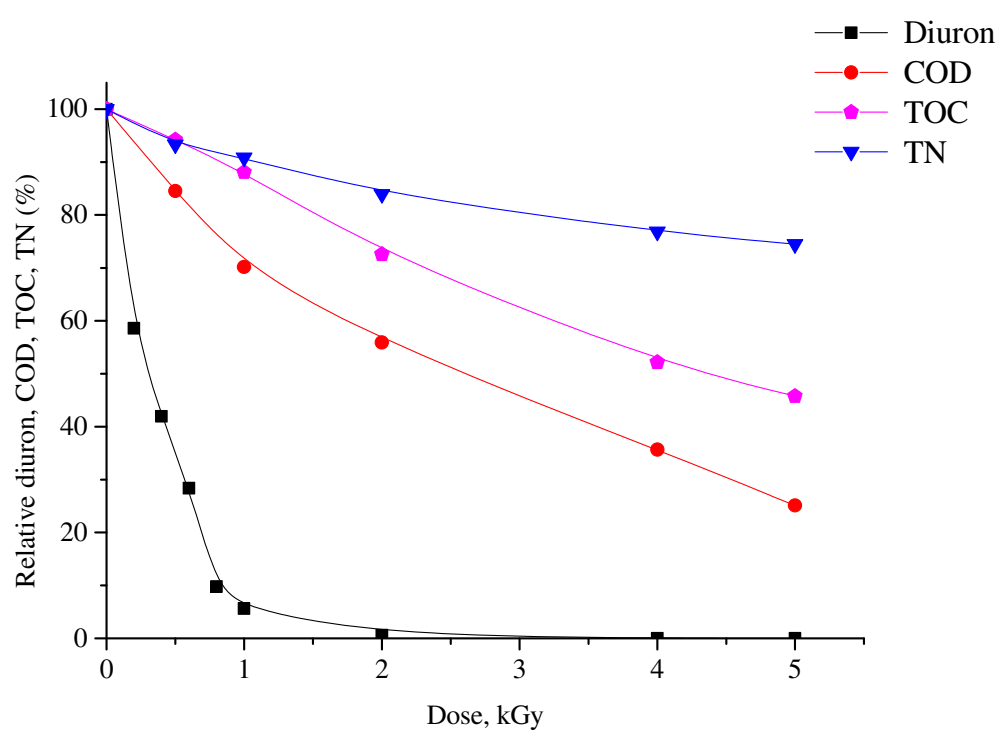

Figure $6 \mathrm{TOC}, \mathrm{COD}$ and TN results and removal of diuron. All of the experiments were carried out in $1.2 \times 10^{-4} \mathrm{~mol} \mathrm{dm}^{-3}$ diuron solutions before irradiation and after irradiating with various doses.

\section{Removal of COD, TOC and TN}

By measuring the changes of COD and TOC after irradiation, we monitored the rates of oxidation and mineralization. The TN measurements show whether the $\mathrm{N}$ content remains in the solution after degradation, or it leaves the solution in the form of $\mathrm{N}_{2}$. These measurements were conducted on samples saturated with air. COD and TOC decreased steadily with the absorbed dose (Figure 6), the decrease in COD was higher than in TOC. Partly oxidized molecules need less $\mathrm{O}_{2}$ for complete mineralization than the intact ones; however, their organic carbon content is similar to those of the starting molecules. For instance, in air saturated solutions at $1 \mathrm{kGy}$ dose the decrease of COD and TOC was $30 \%$ and $7 \%$, respectively. At this dose, about $95 \%$ of diuron was depleted. This result is similar to the one obtained by Zhang et al. [10] using $7.9 \times 10^{-5} \mathrm{~mol} \mathrm{dm}^{-3}$ diuron concentration; they found practically $100 \%$ removal of the starting molecules and $34 \%$ TOC removal. TN decreased only slightly during the treatment showing that nitrogen mainly remained in the liquid phase.

The initial slope of the COD-dose plot is c.a. $11 \mathrm{mg}$ $\mathrm{dm}^{-3} \mathrm{kGy}^{-1}$, so at $1 \mathrm{kGy}$ dose $\sim 3.4 \times 10^{-4} \mathrm{~mol} \mathrm{dm}{ }^{-3} \mathrm{O}_{2}$ was built in the products. At this dose $2.8 \times 10^{-4} \mathrm{~mol}$ $\mathrm{dm}^{-3} \cdot \mathrm{OH}$ was introduced into the solution, the $\mathrm{O}_{2}$ molecules built-in $/{ }^{\circ} \mathrm{OH}$ introduced into the solution molar ratio is c.a. 1.2. When an $\mathrm{O}_{2}$ is incorporated in a product four-electron oxidation occurs. Therefore ${ }^{\circ} \mathrm{OH}$, the oneelectron oxidant, induces more than four-electron oxidations.

\section{Discussion}

Using the UV spectroscopic and LC-MS/MS results, the yields of diuron degradation are calculated to be in the $0.15-0.3 \mu \mathrm{mol} \mathrm{J}^{-1}$ range. The $G$-values of chloride release are between $0.07-0.15 \mu \mathrm{mol} \mathrm{J}{ }^{-1}$ (two $\mathrm{Cl}$-atom elimination). Based on the COD values measured in air saturated solution the $\mathrm{O}_{2} /{ }^{\circ} \mathrm{OH}$ ratio is c.a. 1.2. The value is much higher than the ratio established for fenuron, $\sim 0.7$ [11] and it is also higher than found for the majority of molecules studied so far in our laboratory (0.25-1.0 [17-19]). The high ratio in the present study indicates effective diuron degradation in air saturated solution.

'OH is expected to add to any of the carbon atoms of the aromatic ring. The addition at a carbon atom bearing the chlorine atom (8), may be followed by $\mathrm{HCl}$ elimination (9) as it was shown e.g. for diclofenac [20,21]. Canle Lopez et al. [5] suggest such chlorine release in

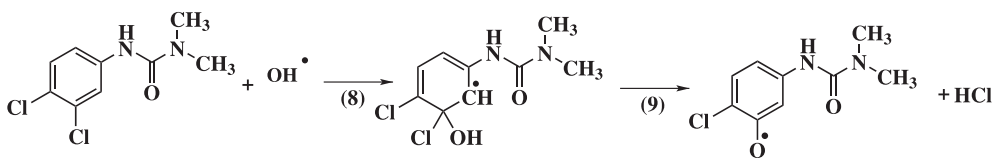

Scheme $1{ }^{\circ} \mathrm{OH}$ attack to diuron at the meta-position. 


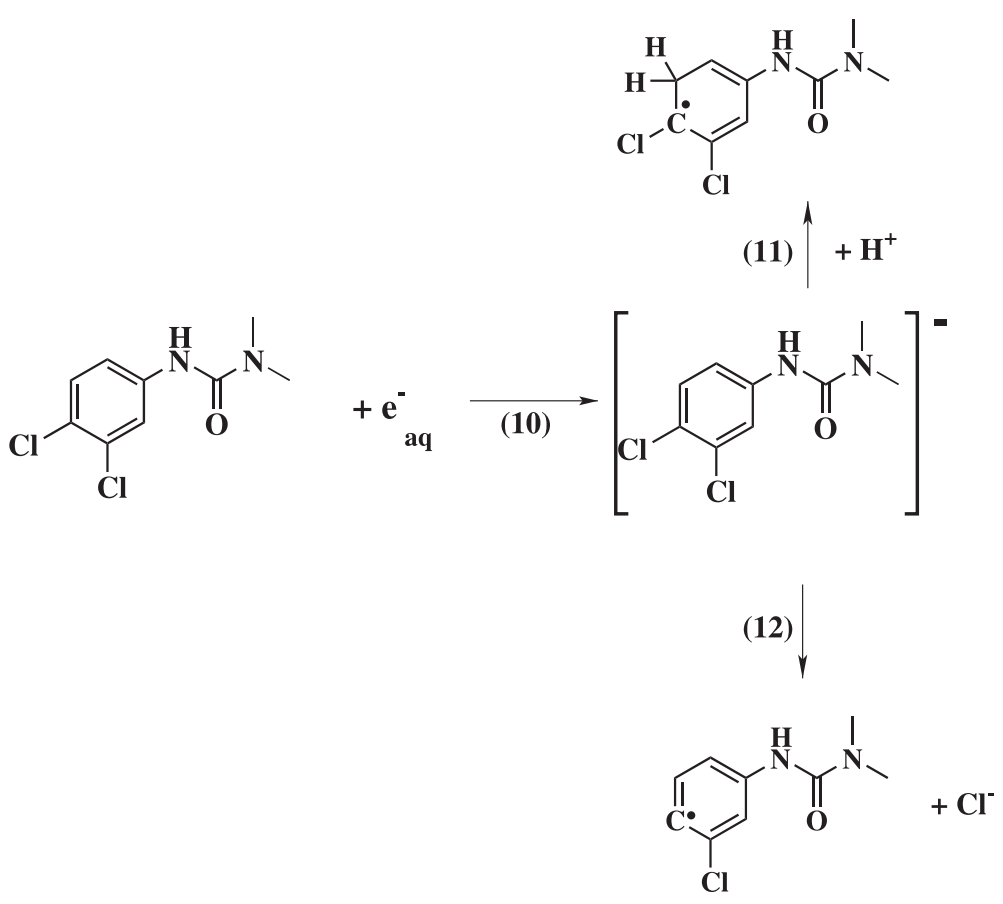

Scheme 2 Reactions of $e_{\text {aq }}^{-}$with diuron.

photocatalytic oxidation of diuron, too. ${ }^{\circ} \mathrm{OH}$ attack at the meta-position is shown in Scheme 1.

This reaction ultimately gives rise to phenoxyl type radical formation, the absorption bands in the transient spectrum at $\sim 330 \mathrm{~nm}$ and at $\sim 460 \mathrm{~nm}$ are probably due to this transient intermediate (Figure 1). The dechlorination yields in both $\mathrm{N}_{2} \mathrm{O}$ bubbled and air saturated solutions are smaller than the ${ }^{\circ} \mathrm{OH}$ yields. Only a small fraction of ${ }^{\circ} \mathrm{OH}$ reaction leads to dechlorination. Based on the higher dechlorination yield in aerated solution compared to $\mathrm{N}_{2} \mathrm{O}$-saturated solution, one may think that the $\mathrm{O}_{2}^{-\bullet} / \mathrm{HO}_{2}^{-}$pair also induces dechlorination. $\mathrm{O}_{2}^{-\bullet}$ is a reductive radical with standard one-electron reduction potential of $-0.33 \mathrm{~V}$ ( $v s$. NHE) [22], while the standard one-electron reduction potential of diuron is calculated to be $1.72 \mathrm{~V}$ [23]. The dechlorination of chloroanilines in microbial experiments is demonstrated in several papers [24]: in the case of dichloroanilines first the para- and then the metachlorines are involved in the process. In our experiments carried out in the presence of $\mathrm{Na}$ formate, when $\mathrm{O}_{2}^{-\bullet}$ is the main reactive species, just a small dechlorination was found. Because of the low yield one may also think that the dechlorination is due to some side reaction in these solutions, e.g. small fraction of ${ }^{\cdot} \mathrm{OH}$ or $\mathrm{e}_{\mathrm{aq}}^{-}$is not scavenged by $\mathrm{HCO}_{2}^{-}$or $\mathrm{O}_{2}$, respectively, and reacts with diuron inducing dechlorination. In the photocatalytic experiments of Canle Lopez et al. [5] a competition was found between the reactions of $\mathrm{e}^{-}$, transferred to the conduction band, with $\mathrm{O}_{2}$ and with diuron. Based on our experiments we may say that dissolved $\mathrm{O}_{2}$ in the solution promotes the $\mathrm{Cl}^{-}$elimination from the adduct. Low reactivity of the $\mathrm{O}_{2}^{-*} / \mathrm{HO}_{2}^{*}$ pair with aromatic molecules was also reported in other works $[18,25]$.

The rate coefficient of hydrated electron reaction with diuron is one order of magnitude higher than with fenuron due to the enhanced electron-withdrawing effect of the two $\mathrm{Cl}$ atoms attached to the aromatic ring. The electron is accommodated on the ring and the adduct undergoes reversible protonation with $\mathrm{p} K_{\mathrm{a}}$ of $4.30 \pm 0.04$ [3]. The results in Figure 3 show that about $25 \%$ of the $\mathrm{e}_{\mathrm{aq}}^{-}$reactions induce chloride release. The mechanism suggested for chloride release is shown in Scheme 2, Reaction (12).

The phenyl radicals formed in (12) may be stabilized in bimolecular radical-radical or radical-molecule reactions. The expected products are molecules with one chlorine atom on the ring in para- (monuron) or in meta-position. These products were observed in our LCMS/MS investigations, however, with quite low yields.

In the present work and also in most of other AOP experiments, where $\mathrm{OH}$ played important role in the degradation [3-7], phenol type molecules were observed as important intermediate products. These phenols may form through the identified transient intermediates, hydroxycyclohexadienyl radicals shown in Scheme 3, Reaction (13).

In the absence of dissolved $\mathrm{O}_{2}$ the hydroxycyclohexadienyl radicals decay in bimolecular reaction with other 


$$
\text { (13) }
$$

Scheme 3 Reactions of ${ }^{\circ} \mathrm{OH}$ with diuron in the presence and in the absence of $\mathrm{O}_{2}$.

radicals $\left(R^{*}\right)$ present: the reaction may yield phenol type molecules (Scheme 3, Reaction (14)). In the presence of dissolved $\mathrm{O}_{2}$ the transient radicals can transform to peroxy radicals (Reaction (15)). The peroxy radicals formed from hydroxycyclohexadienyl radicals may either eliminate $\mathrm{HO}_{2}^{*}$ forming phenol compounds (Reaction (16)) or may undergo stepwise oxidation to open-chain carboxylic acids. These reaction pathways are well known for different aromatics [26,27]. The high degradation rate in air saturated solutions, as compared to reactions under other conditions, can be attributed to the involvement of oxygen in the process.

Products that reflect ${ }^{\circ} \mathrm{OH}$ reaction with a methyl group were also observed in the presence of dissolved $\mathrm{O}_{2}$. However, based on the abundances it seems that $\cdot \mathrm{OH}$ predominantly reacts with the aromatic ring and not with the methyl groups.

\section{Conclusions}

During irradiation of dilute diuron solutions effective degradation was observed, which was higher under oxidative than reductive conditions. Under oxidative circumstances the intermediate products observed were similar to those found in other Advanced Oxidation Processes: hydroxylation in the ring, hydroxylation coupled to chlorine release and products reflecting reactions on one of the methyl groups. The presence of dissolved oxygen enhanced the rate of degradation. As the $\mathrm{COD}$ values show, the one-electron-oxidant ${ }^{\circ} \mathrm{OH}$ on average induces five-electron oxidations. The high oxidation rate is attributed to the reactions of the primarily formed radicals with dissolved $\mathrm{O}_{2}$ and the subsequent reactions of the peroxy radical.

\section{Competing interest}

The authors declare that they have no competing interest.

\section{Authors' contributions}

K.K. carried out the pulse radiolysis, the AOX, COD, TOC, and TN measurements and evaluated the results. SH took the UV-Vis spectra, participated in the pulse radiolysis experiments and drafted part of the manuscript. VM participated in the pulse radiolysis experiments. TCs carried out the HPLC-MS/MS measurements and evaluated the results of this measurement. ET and LW participated in evaluation of the results and prepared the final draft of the manuscript. All authors read and approved the final manuscript.

\section{Acknowledgement}

The authors thank Hungarian Science Foundation (OTKA, NK 105802) and International Atomic Energy Agency (Contract No. 16485) for support. International Atomic Energy Agency is also thanked for financing the scientific training of Dr. He.

\section{Author details}

${ }^{1}$ Institute for Energy Security and Environmental Safety, Centre for Energy Research, Hungarian Academy of Sciences, Budapest, Hungary. ${ }^{2}$ Institute of Nuclear and New Energy Technology (INET), Tsinghua University, Beijing 100084, China. ${ }^{3}$ Faculty of Light Industry and Environmental Engineering, Obuda-University, Budapest, Hungary.

Received: 5 November 2014 Accepted: 6 April 2015

Published online: 18 April 2015 


\section{References}

1. European Commission. Decision no. 2455/2001/EC of the European Parliament and of the Council of 20 November 2001, establishing the list of priority substances in the field of water policy and amending directive 2000/60/EC. Official J Eur Communities L Ser. 2001;331:1-5.

2. U.S. Environmental Protection Agency. Fact Sheet: The Drinking Water Contaminant Candidate List - The Source of Priority Contaminants for the Drinking Water Program. Washington DC: U.S. Environmental Protection Agency; 2005

3. Canle LM, Rodrígez S, Rodrígez Vazques LF, Santaballa JA, Steenken S. First stages of photodegradation of the urea herbicides Fenuron, Monuron and Diuron. J Mol Struct. 2001;565-566:133-9.

4. Tahmasseb LA, Néhliu S, Kerhoas L, Einhorn J. Ozonation of chlorophenylurea pesticides in water: reaction monitoring and degradation pathways. Sci Total Environ. 2002;291:33-44.

5. Canle LM, Fernandez MI, Rodrígez S, Santaballa JA, Steenken S, Vulliet E. Mechanisms of direct and $\mathrm{TiO}_{2}$-photocatalised UV degradation of phenylurea herbicides. Chemphyschem. 2005;6:2064-74.

6. Salvestrini S, Di Cerbo P, Capasso S. Kinetics of the degradation of diuron. Chemosphere. 2002;48:69-73.

7. Oturan MA, Edelahi MC, Oturan N, El Kacemi K, Aaron J-J. Kinetics of oxidative degradation/mineralization pathways of the phenylurea herbicides diuron, monuron and fenuron in water during application of the electro-Fenton process. Appl Catal Environ. 2010;97:82-9.

8. Mazellier P, Sulzberger B. Diuron degradation in irradiated, heterogeneous iron/oxalate systems: the rate determining step. Environ Sci Tech. 2001;35:3314-20.

9. Radiation Processing: Environmental Applications, 2007. International Atomic Energy Agency, Vienna, ISBN 92-D-100507-5.

10. Zhang J, Zheng Z, Zhao T, Zhao Y, Wang L, Zhong Y, et al. Radiation-induced reduction of diuron by gamma-ray irradiation. J Hazard Mater. 2008;151:465-72

11. Kovács K, Mile V, Csay T, Takács E, Wojnárovits L. Hydroxyl radical-induced degradation of fenuron in pulse and gamma radiolysis: kinetics and product analysis. Environ Sci Pollut Res. 2014;21:12693-700.

12. Sági G, Csay T, Szabó L, Pátzay G, Csonka E, Takács E, et al. Analytical approaches to the $\mathrm{OH}$ radical induced degradation of sulfonamide antibiotics in dilute aqueous solutions. J Pharm Biomed Anal. 2015;106:52-60.

13. Buxton G, Greenstock CL, Helman WP, Ross AB. Critical review of rate constants for reactions of hydrated electrons, hydrogen atoms and hydroxyl radicals ('OH/O') in aqueous solution. J Phys Chem Ref Data. 1988;17:513-886.

14. Spinks JWT, Woods RJ. An Introduction to Radiation Chemistry. 3rd ed. New York: Wiley-Interscience; 1990

15. Singh TS, Gejji SP, Rao BMS, Mohan H, Mittal JP. Radiation chemical oxidation of aniline derivatives. J Chem Soc Perkin 2. 2001;7:1205-11.

16. Wojnárovits $L$, Takács $E$. Rate coefficients of hydroxyl radical reactions with pesticide molecules and related compounds: a review. Radiat Phys Chem. 2014;96:120-34.

17. Csay T, Homlok R, Illés E, Takács E, Wojnárovits L. The chemical background of Advanced Oxidation Processes. Israel J Chem. 2014;54:233-41.

18. Sági G, Csay T, Pátzay G, Csonka E, Wojnárovits L, Takács E. Oxidative and reductive degradation of sulfamethoxazole in aqueous solutions. J Radionalytical Nucl Chem. 2014;301:475-82.

19. Homlok R, Takács E, Wojnárovits L. Degradation of organic molecules in advanced oxidation processes: relation between chemical structure and degradability. Chemosphere. 2013;91:383-9.

20. Homlok R, Takács E, Wojnárovits L. Elimination of diclofenac from water using irradiation technology. Chemosphere. 2011;85:603-8.

21. Sein MM, Zedda M, Tuerk J, Schmidt TC, Gollach A, von Sonntag C. Oxidation of diclofenac with ozone in aqueous solution. Environ Sci Tech. 2008;42:6656-62

22. Bielski $\mathrm{BH}$, Cabelli $\mathrm{DE}$, Arudi $\mathrm{RL}$, Ross $A B$. Reactivity of $\mathrm{HO}_{2}^{*} / \mathrm{O}_{2}^{-*}$ radicals in aqueous solution. J Phys Chem Ref Data. 1985;14:1041-100.

23. Arnold WA. One electron oxidation potentials as a predictor of rate constants of $\mathrm{N}$-containing compounds with carbonate and triplet excited state organic matter. Environ Sci Processes Impacts. 2014;16:832-8.

24. Susarla S, Masunaga S, Yonezawa Y. Redox potential as a parameter to predict the reductive dechlorination pathway of chloroanlines in aerobic environments. Microb Ecol. 1997;33:252-6.
25. Jovanovic SV, Hara Y, Steenken S, Simic MG. Antioxidant potential of gallocatechins. A pulse radiolysis and laser photolysis study. J Am Chem Soc. 1995;117:9881-8.

26. von Sonntag C, Schuchmann H-P. Peroxyl radicals in aqueous solution. In: Alfassi ZB, editor. Peroxy-Radicals. Chichester, England: John Wiley and Sons; 1997.

27. von Sonntag C. Free-Radical-Induced DNA Damage and its Repair, A Chemical Perspective. Heidelberg: Springer; 2006.

\section{Publish with ChemistryCentral and every scientist can read your work free of charge \\ "Open access provides opportunities to our colleagues in other parts of the globe, by allowing anyone to view the content free of charge." \\ W. Jeffery Hurst, The Hershey Company.}

- available free of charge to the entire scientific community

- peer reviewed and published immediately upon acceptance

- cited in PubMed and archived on PubMed Central

- yours - you keep the copyright

Submit your manuscript here:

http://www.chemistrycentral.com/manuscript/<smiles>c1ccccc1</smiles>

ChemistryCentral 